\title{
STUDY AND MODELING OF EXTRACTION PROPERTIES OF FLUOROORGANIC SOLVENTS IN REGARD TO LOW-POLAR BIOLOGICALLY ACTIVE SUBSTANCES FROM PLANT RAW MATERIALS
}

\author{
NIKOLAY N. BOYKO ${ }^{1 *}$, ELENA T. ZHILYAKOVA ${ }^{2}$, OLEG O. NOVIKOV ${ }^{1}$, DMITRIY I. \\ PISAREV ${ }^{1}$, RIMMA A. ABRAMOVICH ${ }^{1}$, OLGA G. POTANINA ${ }^{1}$, SIMON LAZAR ${ }^{1}$, \\ OLEKSANDR I. GUTOROV ${ }^{3}$, LARYSA N. ANDRIUKOVA ${ }^{4}$, OLEH S. SHPYCHAK ${ }^{4}$ \\ ${ }^{1}$ Peoples' Friendship University of Russia, 8/2 Miklukho-Maklay Street, 117198, Moscow, Russia \\ ${ }^{2}$ Belgorod National Research University, 85 Pobedy Street, 308015, Belgorod, Russia \\ ${ }^{3}$ National University of Pharmacy, 53 Pushkinska Street, 61002, Kharkiv, Ukraine \\ ${ }^{4}$ Donetsk National Medical University, 41 Tsentralna Street, 84122, Sloviansk, Ukraine \\ *corresponding author: boykoniknik@gmail.com
}

Manuscript received: February 2020

\begin{abstract}
The goal of this work was the studying and modelling of the extraction properties of fluoroorganic solvents in regard to lowpolar biologically active substances (BAS) from plant raw materials (PRM). Anethum graveolens L., Foeniculum vulgare Mill., Pastinaca sativa L., Pimpinella anisum L., Silybum marianum L. fruits, Curcuma longa L. roots, Eucalyptus viminalis Labill., Laurus nobilis L. leaves, Hypericum perforatum L. herbs, and Syzygium aromaticum L. buds were used. As solvents, we used Novec 1230, Novec 7100, MR6S4, and R141b. Quantitative and qualitative analyses of BAS were carried out by RP HPLC and GC-MS. We also used a circulating method in Soxhlet apparatus. A mathematical model that quantitatively describes the extraction properties of fluoroorganic solvents using molecular descriptors such as the relative fraction of fluorine atoms in the molecule of the fluoroorganic solvent and LTPSA has been developed.
\end{abstract}

\section{Rezumat}

În acest studiu au fost evaluate proprietățile extractive ale solvenților fluoroorganici, ținând cont de polaritatea substanțelor (BAS) din materiile prime vegetale (PRM). Au fost utilizate fructele de Anethum graveolens L., Foeniculum vulgare Mill., Pastinaca sativa L., Pimpinella anisum L., Silybum marianum L., rădăcinile de Curcuma longa L., frunzele de Eucalyptus viminalis Labill., Laurus nobilis L., partea aeriană de Hypericum perforatum L. și mugurii de Syzygium aromaticum L.. Solvenții folosiți au fost Novec 1230, Novec 7100, MR6S4 și R141b. Analizele cantitative și calitative ale BAS au fost efectuate folosind ca metode RP-HPLC și GC-MS. S-a dezvoltat un model matematic care descrie cantitativ proprietățile de extracție ale solvenților fluoroorganici cu descriptori moleculari.

Keywords: fluoroorganic solvents, extraction properties, mathematical model

\section{Introduction}

Currently, separation of low-polar biologically active substances (BAS) from plant raw materials with the use of liquefied gases and supercritical fluids are considered to be the most promising technologies in the world [1-5].

It is conditioned by the fact that these technologies have a number of advantages: high yield of low-polar BAS (90\% - 98\%), sparing extraction conditions, environmental, fire, and explosion safety, low toxicity to humans.

However, these technologies also have a number of significant drawbacks: the need to use special equipment that has to operate under excessive pressure (2 - 350 bar), the need to use a refrigeration unit for vapour condensation, additional energy costs for the operation of the refrigeration unit, low selectivity of extraction of fatty oils and essential oils between each other, etc. It should be noted that only in the supercritical state (at elevated temperature and high pressure), carbon dioxide allows selective separation of essential oils from vegetable raw materials in their joint presence with triglycerides [6].

Therefore, it is urgent to search for new solutions in the technology of selective isolation of low-polar BAS from PRM, which allow avoiding the above disadvantages.

One of such innovative solutions can be the use of fluoroorganic solvents owing to their unique physical and chemical properties driven by the presence of fluorine atoms in the carbon skeleton of the molecule, which gives them weak intermolecular forces and 
causes these substances to have low boiling points, evaporation heat, heat capacity, surface tension, toxicity, and also gives them hydrophobic and even lipophobic properties [7].

The analysis of the literature revealed that at the moment, fluoroorganic solvents of a new generation have appeared on an industrial scale in Russia; they have the advantages in a number of parameters in comparison to liquefied gases and supercritical fluids. Some fundamental parameters of fluoroorganic solvents and liquefied gases (from the technological point view) are presented in Table I [8-13].

Table I

Some fundamental parameters of fluoroorganic solvents and liquefied gases

\begin{tabular}{|c|c|c|c|c|c|c|c|c|}
\hline \multirow[b]{2}{*}{ Parameter } & \multicolumn{8}{|c|}{ Type of fluoroorganic solvent and liquefied gas } \\
\hline & $\begin{array}{l}\text { Oे } \\
\text { İ } \\
0 \\
0 \\
0 \\
z\end{array}$ & $\begin{array}{l}8 \\
\frac{8}{1} \\
0 \\
0 \\
0 \\
z\end{array}$ & 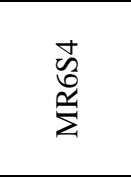 & $\frac{\partial}{\frac{\partial}{\sim}}$ & $\widetilde{\widetilde{z}}$ & $\frac{\mathbb{J}}{\stackrel{\Xi}{\overparen{Z}}}$ & $\underset{\approx}{\infty}$ & $\frac{7}{\stackrel{J}{\alpha}}$ \\
\hline 1. Empirical formula & 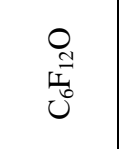 & 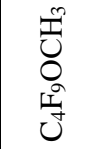 & $\begin{array}{l}\stackrel{5}{0} \\
\underset{J}{\mathcal{J}}\end{array}$ & 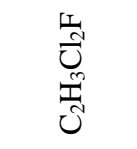 & 氖 & 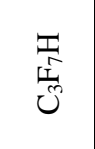 & $\stackrel{L}{+\infty}^{+\infty}$ & ర \\
\hline 2. Molecular weight, $\mathrm{g} / \mathrm{mol}$ & 316 & 250 & 200 & 117 & 67 & 170 & 200 & 44 \\
\hline 3. Pressure $20^{\circ} \mathrm{C}, \mathrm{MPa}$ & 0.040 & 0.027 & 0.020 & 0.081 & 0.91 & 0.391 & 0.272 & 6.0 \\
\hline 4. Boiling point, ${ }^{\circ} \mathrm{C}$ & 49 & 61 & 59 & 32 & -41 & -16 & -6 & -79 \\
\hline 5. Heat of vaporization, $\mathrm{kJ} / \mathrm{L}$ & 141 & 169 & 214 & 257 & 278 & 181 & 178 & 144 \\
\hline 6. Density $20^{\circ} \mathrm{C}, \mathrm{kg} / \mathrm{m}^{3}$ & 1,600 & 1,510 & 1,520 & 1,240 & 1,200 & 1,407 & 1,517 & 930 \\
\hline 7. Dielectric constant & $1.8-2.3$ & 7.4 & $\mathrm{n} / \mathrm{a}$ & 8.1 & 3.1 & 2.0 & 1.0 & 1.6 \\
\hline 7. Global warming potential (GWP) & 1 & 320 & $204-575$ & $630-782$ & 1,760 & 3,300 & 10,300 & 1 \\
\hline 8. Ozone depletion potential (ODP) & 0 & 0 & 0.02 & 0.12 & 0.055 & 0 & 0 & 0 \\
\hline 9.Toxicity, ppm & 4,000 & 750 & 4 & 500 & 1,000 & 1,000 & 1,000 & 5,000 \\
\hline 10. Approx. price as to $08 / 2019$, US dollars per $\mathrm{kg}$ & $40 \pm 4$ & $95 \pm 9$ & 405 & $13 \pm 2$ & $12 \pm 2$ & $22 \pm 2$ & $40 \pm 5$ & 0.15 \\
\hline
\end{tabular}

As can be seen from the data in Table I, fluoroorganic solvents in many physical, chemical, environmental, and toxicological parameters do not differ very much from freons, but are inferior to carbon dioxide. At the same time, their price is slightly higher than that of freons and much higher than of carbon dioxide, which is one of the limiting factors of their widespread use in industry.

However, owing to their unique properties, these solvents are increasingly being used in various sectors of the economy as solvents, heat-conducting liquids, and fire extinguishing agents [14-15].

As a result of the patent search, we have found only a few patents in the EU and the US, regarding the methods for extraction of fatty and essential oils from vegetable raw materials using fluoroorganic solvents or their mixture with other solvents [16-18].

These results show the availability of limited information on the extraction properties of fluoroorganic solvents for use in the pharmaceutical industry, as well as high prospects for research in this field.

Taking into account the above material, we have conducted systematic studies on the extraction properties of fluoroorganic solvents with respect to various low-polar BAS, and on their basis, an attempt is made to explain theoretically and describe quantitatively the experimental data obtained.

The goal of this work was the studying and modelling of the extraction properties of fluoroorganic solvents in regard to low-polar biologically active substances (BAS) from plant raw materials (PRM).

\section{Materials and Methods}

\section{Plant raw materials}

Ground plant raw materials with a particle size of $0.1-0.5 \mathrm{~mm}$ were used for research: Anethum graveolens L. fruits, LLC Pharmaceutical shop "Medicinal plants", Kharkiv, Ukraine, batch no. 981117, bbd 09/2020. Curcuma longa L. roots, "Goldiee", Nayaganj, Kanpur, India, batch no. 827, bbd 01/2020. Foeniculum vulgare Mill. fruits, LLC Pharmaceutical shop "Medicinal plants", Kharkiv, Ukraine, batch no. 135117, bbd 08/2020. Eucalyptus viminalis Labill. leaves, "Krasnogorskleksredstva" company, Krasnogorsk, Russia, batch no. 100917, bbd 10/2020. Hypericum perforatum L. herbs, LLC Pharmaceutical shop "Medicinal plants", Kharkiv, Ukraine, batch no. 120717, bbd 07/2019. Laurus nobilis L. leaves, LLC “Standart”, Krasnodar, Russia, batch no. 02042019, bbd 04/2020. Pastinaca sativa L. fruits (Globular cultivar), "Pnsemena" company, Ukraine, batch no. 454124, bbd 12/2021. Pimpinella anisum L. fruits, LLC Pharmaceutical shop "Medicinal plants", Kharkiv, Ukraine, batch no. 135117, bbd 08/2020. Silybum marianum L. fruits, "Biocor" company, Penza, Russia, batch no. 040919, bbd 09/2021. Syzygium aromaticum L. buds, "Lechec" firm, Kharkiv, Ukraine, batch no. 082018, bbd 08/2020. 
Chemicals

Carvone (CAS 6485-4D-1); eugenol (CAS 97-53-0); trans-anethole (CAS 4180-23-8), xanthotoxin (CAS 298-81-7) were from Sigma-Aldrich, Merck, with content $\geq 98.0 \%$; evcalimin standard sample of the All Russian Scientific Research Institute of Medicinal and Aromatic Plants (a sum of macrocarpales); spissum extract of Chlorophyllipt of the State Pharmacopoeia of Ukraine (a sum of cupric chlorophylls, euglobals with monoterpenoid structure and macrocarpales), were used as reference substances.

Fluoroorganic solvents

Novec 1230 and Novec 7100 were from the USA, 3M Company; MR6S4 was from Great Britain, Aesica Queenborough Ltd; R141b DGX was from France, Arkema Inc., with content $\geq 99.0 \%$.

Reverse phase high performance liquid chromatography (RP HPLC)

Analysis of biologically active substances was carried out using the method of RP HPLC on Agilent Technologies device, series Agilent 1200 Infinity, USA. The process of analysis was carried out under the following conditions: $1 \%$ aqueous solution of formic acid was used as mobile phase (A), and ethanol $96 \%$ vol. was used as mobile phase (B), with a linear gradient elution mode; mobile phase velocity was $0.5 \mathrm{~mL} / \mathrm{min}$; chromatographic column: Supelco Ascentis express C18, length $100 \mathrm{~mm}$, internal diameter 4.6 $\mathrm{mm}$, particle size $2.7 \mu \mathrm{m}$; chromatographic column temperature: $35^{\circ} \mathrm{C}$; sample volume: $1 \mu \mathrm{L}$. The conditions for RP HPLC analysis were the same as in the work by Zhilyakova et al. [19]. Analytical wavelengths: $240 \mathrm{~nm}$ (carvone), $275 \mathrm{~nm}$ (euglobals and macrocarpales), $280 \mathrm{~nm}$ (eugenol), $284 \mathrm{~nm}$ (anethole) and $302 \mathrm{~nm}$ (xanthotoxin).

GC-MS method of analysis

Qualitative analysis of extracts was carried out by GC-MS method using equipment GCMS-QP2010 Ultra with a mass analyser, by Shimadzu, Japan. Column: Zebron ZB-5MS, length $30 \mathrm{~m}$, inside diameter $0.25 \mathrm{~mm}$, film thickness $0.25 \mu \mathrm{m}$; liquid phase: $5 \%-$ polysilarylene and $95 \%$ - polydimethylsiloxane; temperature settings: from $70^{\circ} \mathrm{C}$ to $325 / 350^{\circ} \mathrm{C}$. Gascarrier: helium with a stable flow of $3.0 \mathrm{~mL} / \mathrm{min}$. Detection regime: total ion current (SCAN) in the range $\mathrm{m} / \mathrm{z}$ from 30 to $500 \mathrm{Da}$ with scanning velocity 1,000 and result time $0.5 \mathrm{sec}$. The injection volume was $1 \mu \mathrm{L}$. Method of extraction

A sample of ground plant raw material weighing $5.00 \mathrm{~g}$ (particle size $0.1-0.5 \mathrm{~mm}$ ) was placed in the Soxhlet extractor; the raw material was poured with $25.0 \mathrm{~mL}$ of the extractant and extracted for a specified period. The resulting solution was evaporated until an extract was obtained, and the latter was blown with airflow for 5 - 10 minutes. The extract was dissolved in ethanol $96 \%$ vol. The solution was weighed, its density was determined, and it was analysed for the content of biologically active substances using the method of RP HPLC.

\section{Theoretical part}

To construct a mathematical model that quantitatively describes the extraction properties of fluoroorganic solvents, the authors used two working hypotheses based on the laws of physical and colloidal chemistry and two molecular descriptors [20, 21].

Working hypothesis 1: the extraction properties of fluoroorganic solvents should be associated with a change of chemical potential in the extraction system, which is represented by two types of Gibbs energies: surface energy $\left(\Delta G_{l}\right)$ and interaction energy of BAS molecules with solvent molecules $\left(\Delta G_{2}\right)$.

Working hypothesis 2 : surface energy $\left(\Delta G_{l}\right)$ is directly proportional to the limit value TPSA of BAS molecule for fluoroorganic solvent (LTPSA), and interaction energy of BAS molecules with solvent molecules $\left(\Delta G_{2}\right)$ is directly proportional to the product of surface energy and the exponent of the relative fraction of fluorine atoms in the molecule of fluoroorganic solvent $\left(1-\varphi_{F}\right)$. These working hypotheses are presented below in equations (1) - (4):

$$
\begin{aligned}
& R T \cdot \ln \left(\frac{N_{0}-N}{N}\right)=\Delta \mu, \\
& \Delta \mu=\Delta G_{1}+\Delta G_{2},
\end{aligned}
$$

where $R$ is gas constant, $8.314, \mathrm{~J} /(\mathrm{mol} \cdot \mathrm{K})$;

$T$ is absolute temperature, $\mathrm{K}$;

$N_{0}$ is the total amount of BAS in the extraction system, mol;

$N$ is the amount of BAS in the solvent, mol;

$\Delta \mu$ is change of chemical potential, $\mathrm{J}$;

$\Delta G_{l}$ is a change in Gibbs energy ( $\mathrm{J}$ ) due to changes in surface energy, which is associated with molecular descriptor LTPSA, equation (3):

$$
\Delta G_{1}=\sigma \cdot L T P S A,
$$

where $\sigma$ is solvent surface tension, $\mathrm{N} / \mathrm{m}^{2}$;

LTPSA is the experimental value of the limit value of the molecular descriptor TPSA for molecules of low-polar BAS extracted by solvent, $\AA^{2}$;

$\Delta G_{2}$ is a change of Gibbs energy (J) due to energy of interaction of BAS molecules with solvent molecules, expressed in terms of surface energy and parameter $\left(1-\varphi_{F}\right)$, in the form of equation (4):

$$
\Delta G_{2}=\sigma \cdot L T P S A \cdot \exp \left[k \cdot\left(1-\varphi_{F}+b\right)\right],
$$

where $\varphi_{F}$ is the relative fraction of fluorine atoms in the solvent molecule;

$k$ and $b$ are empirical constants.

In the case of the adequacy of equations (2) - (4), as well as under the additional condition that $\Delta \mu=\sigma \cdot A=$ const, the experimental data should be well approximated by sigma function having the following form (5):

$$
L T P S A=\frac{A}{1+\exp \left[k \cdot\left(1-\varphi_{F}+b\right)\right]},
$$


Parameter $\left(\varphi_{F}\right)$ was calculated by equation (6):

$$
\varphi_{F}=\frac{n_{F}}{\sum n_{i}},
$$

where $n_{F}$ is the number of fluorine atoms in the solvent molecule, units;

$n_{i}$ is the number of $i$-atoms in the solvent molecule, units.

A molecular TPSA descriptor for BAS was found in PubChem Database [13].

\section{Calculation method}

Regression analysis was used to determine the degree of consistency between the theoretically developed mathematical model (5) and the experimentally

obtained data. At the same time, the values of constants and their errors were found using Origin 6.1 program.

\section{Results and Discussion}

In the first part of the research, systematic studies of the extraction properties of fluoroorganic solvents Novec 1230, Novec 7100, MR6S4, and R141b were carried out with respect to various types of lowpolar BAS from plant raw materials (mainly from essential oils), the materials of which are partially presented in such works as [22-24].

In this case, the extraction of BAS from plant raw materials was carried out using the circulation method in Soxhlet apparatus for three hours. The results of the studies are presented in Table II.

Table II

Results of systematic studies on the extraction properties of fluoroorganic solvents

\begin{tabular}{|c|c|c|c|c|}
\hline Type of PRM & Type of BAS & Yield of BAS, \%* & Type of solvent & Note \\
\hline \multirow{2}{*}{$\begin{array}{l}\text { 1. Anethum } \\
\text { graveolens L. fruits }\end{array}$} & \multirow[t]{2}{*}{ Carvone } & $97 \pm 4$ & Novec 1230 & $\begin{array}{l}\text { Limonene was detected. Triglycerides } \\
\text { were undetected }\end{array}$ \\
\hline & & $95 \pm 4$ & Novec 7100 & Limonene and triglycerides were detected \\
\hline \multirow{4}{*}{$\begin{array}{l}\text { 2. Curcuma longa } \mathrm{L} \text {. } \\
\text { roots }\end{array}$} & \multirow{4}{*}{ Sum of curcuminoids } & None & Novec 1230 & \multirow{4}{*}{$\begin{array}{l}\text { Curcumene, zingiberene, Ar-tumerone and } \\
\text { curlone were detected }\end{array}$} \\
\hline & & None & Novec 7100 & \\
\hline & & $17 \pm 1$ & MR6S4 & \\
\hline & & $16 \pm 1$ & $\mathrm{R} 141 \mathrm{~b}$ & \\
\hline \multirow{2}{*}{$\begin{array}{l}\text { 3. Foeniculum } \\
\text { vulgare Mill. fruits }\end{array}$} & \multirow[t]{2}{*}{ Anethole } & $94 \pm 4$ & Novec 1230 & $\begin{array}{l}\text { Fenchone was detected. Triglycerides were } \\
\text { undetected }\end{array}$ \\
\hline & & $83 \pm 4$ & Novec 7100 & Fenchone and triglycerides were detected \\
\hline \multirow{6}{*}{$\begin{array}{l}\text { 4. Eucalyptus } \\
\text { viminalis Labill. } \\
\text { leaves }\end{array}$} & \multirow{2}{*}{$\begin{array}{l}\text { Euglobals of mono- } \\
\text { terpenoid structure }\end{array}$} & None & Novec 1230 & \multirow{2}{*}{$\begin{array}{l}\text { 1,8-cineole was detected. Chlorophylls and } \\
\text { macrocarpales were undetected }\end{array}$} \\
\hline & & $54 \pm 3$ & Novec 7100 & \\
\hline & $\begin{array}{l}\text { Euglobals of mono- } \\
\text { terpenoid structure }\end{array}$ & $48 \pm 3$ & \multirow[t]{2}{*}{ MR6S4 } & \multirow{4}{*}{ 1,8-cineole and chlorophylls were detected } \\
\hline & Macrocarpales & $44 \pm 2$ & & \\
\hline & $\begin{array}{l}\text { Euglobals mono- } \\
\text { terpenoid structure }\end{array}$ & $99 \pm 4$ & \multirow[t]{2}{*}{$\mathrm{R} 141 \mathrm{~b}$} & \\
\hline & Macrocarpales & $51 \pm 3$ & & \\
\hline \multirow{2}{*}{$\begin{array}{l}\text { 5. Hypericum } \\
\text { perforatum L. herbs }\end{array}$} & \multirow[b]{2}{*}{ Hyperforin } & None & Novec 1230 & - \\
\hline & & $99 \pm 4$ & Novec 7100 & $\begin{array}{l}\text { Adhyperforin was detected. Chlorophylls } \\
\text { were undetected }\end{array}$ \\
\hline \multirow{3}{*}{$\begin{array}{l}\text { 6. Laurus nobilis L. } \\
\text { leaves }\end{array}$} & \multirow{3}{*}{ Eugenol } & $99 \pm 3$ & Novec 1230 & \multirow{2}{*}{$\begin{array}{l}\text { Costunolide, methyl eugenol, 1,8-cineole } \\
\text { were detected }\end{array}$} \\
\hline & & $99 \pm 3$ & Novec 7100 & \\
\hline & & $99 \pm 4$ & $\mathrm{R} 141 \mathrm{~b}$ & $\begin{array}{l}\text { Costunolide, methyl eugenol, 1,8-cineole, } \\
\text { chlorophylls were detected }\end{array}$ \\
\hline \multirow{4}{*}{$\begin{array}{l}\text { 7. Pastinaca sativa } \\
\text { L. fruits }\end{array}$} & \multirow{4}{*}{ Xanthotoxin } & None & Novec 1230 & $\begin{array}{l}\text { Octyl butyrate was detected. Triglycerides } \\
\text { were undetected }\end{array}$ \\
\hline & & $72 \pm 4$ & Novec 7100 & \multirow{3}{*}{$\begin{array}{l}\text { Xanthotoxol, bergapten, octyl butyrate and } \\
\text { triglycerides were detected }\end{array}$} \\
\hline & & $75 \pm 4$ & MR6S4 & \\
\hline & & $66 \pm 3$ & R141b & \\
\hline \multirow{2}{*}{$\begin{array}{l}\text { 8. Pimpinella } \\
\text { anisum L. fruits }\end{array}$} & \multirow{2}{*}{ Anethole } & $99 \pm 4$ & Novec 1230 & Triglycerides were undetected \\
\hline & & $94 \pm 3$ & Novec 7100 & Triglycerides were detected \\
\hline \multirow{4}{*}{$\begin{array}{l}\text { 9. Silybum } \\
\text { marianum L. fruits }\end{array}$} & \multirow{4}{*}{ Triglycerides } & None & Novec 1230 & \multirow{4}{*}{-} \\
\hline & & $\leq 10$ & Novec 7100 & \\
\hline & & $99 \pm 4$ & MR6S4 & \\
\hline & & $99 \pm 4$ & R141b & \\
\hline \multirow{2}{*}{$\begin{array}{l}\text { 10. Syzygium } \\
\text { aromaticum L. buds }\end{array}$} & \multirow{2}{*}{ Eugenol } & $48 \pm 3$ & Novec 1230 & \multirow{2}{*}{$\begin{array}{l}\text { Caryophyllene, humulene, eugenyl acetate } \\
\text { were detected }\end{array}$} \\
\hline & & $86 \pm 5$ & Novec 7100 & \\
\hline
\end{tabular}


FARMACIA, 2020, Vol. 68, 5

As can be seen from the results of Table II, the yield for most of the studied low-polar BAS (anethole, carvone, eugenol, hyperforin, and triglycerides) for three hours of extraction reaches $83-100 \%, 66-75 \%$ for xanthotoxin, $44-53 \%$ for euglobals, and $16-17 \%$ for the sum of curcuminoids. The obtained results were the basis for a number of patents of the Russian Federation for new methods for obtaining essential oils and extracts enriched with target low-polar BAS (furanocoumarins, monoterpene series euglobals, hyperforin, etc.) [25-31]. These results show that the technology of use of fluoroorganic solvents is comparable with those for separation of low-polar BAS from PRM using liquefied gases and supercritical fluids in

terms of fire, explosion, and environmental safety, low toxicity and yield of BAS, but surpasses them in its selectivity, simplicity of organization, and conditions of the extraction process $[1,32,33]$.

In the second part of the research, the analysis of the obtained data was carried out for the possibility of their mathematical formalization, construction of a mathematical model and prediction of the extraction properties of fluoroorganic solvents.

For this purpose, the authors used the following molecular descriptors: relative fraction of fluorine atoms in the solvent molecule $\left(\varphi_{F}\right)$ and topological polar surface area of the low-polar BAS molecule (TPSA). The results obtained are presented in Table III.

Table III

The extraction properties of fluoroorganic solvents and molecular descriptors of low-polar BAS and solvents

\begin{tabular}{|c|c|c|c|c|c|c|}
\hline \multirow[t]{2}{*}{ Type of BAS } & \multicolumn{6}{|c|}{ Type of fluoroorganic solvent } \\
\hline & TPSA, $\AA^{2}$ & Novec 1230 & Novec 7100 & MR6S4 & R12/ R22 [1] & R141b \\
\hline $\begin{array}{l}\text { 1. Caryophyllene, curcumene, humulene, } \\
\text { limonene, zingiberene }\end{array}$ & 0 & $\mathrm{Y}^{*}$ & $\mathrm{Y}$ & $\mathrm{Y}$ & $\mathrm{n} / \mathrm{a}^{* *}$ & $\mathrm{Y}$ \\
\hline 2. Anethole, 1,8 -cineole & 9 & $\mathrm{Y}$ & $\mathrm{Y}$ & $\mathrm{n} / \mathrm{a}$ & $\mathrm{Y}$ & $\mathrm{n} / \mathrm{a}$ \\
\hline 3. Carvone & \multirow{3}{*}{17} & $\bar{Y}$ & $\bar{Y}$ & $\mathrm{n} / \mathrm{a}$ & $\bar{Y}$ & $\mathrm{n} / \mathrm{a}$ \\
\hline 4. Ar-tumerone, curlone & & $\mathrm{Y}$ & $\mathrm{Y}$ & $\mathrm{Y}$ & $\mathrm{n} / \mathrm{a}$ & $\mathrm{Y}$ \\
\hline 5. Fenchone & & $\mathrm{Y}$ & $\mathrm{Y}$ & $\mathrm{n} / \mathrm{a}$ & $\mathrm{n} / \mathrm{a}$ & $\mathrm{n} / \mathrm{a}$ \\
\hline 6. Methyleugenol & 19 & $\mathrm{Y}$ & $\mathrm{Y}$ & $\mathrm{n} / \mathrm{a}$ & $\mathrm{n} / \mathrm{a}$ & $\mathrm{Y}$ \\
\hline 7. Heptyl butyrate & \multirow{2}{*}{26} & $\mathrm{Y}$ & $\mathrm{Y}$ & $\mathrm{Y}$ & $\mathrm{Y}$ & $\mathrm{Y}$ \\
\hline 8. Costunolide & & $\mathrm{Y}$ & $\mathrm{Y}$ & $\mathrm{n} / \mathrm{a}$ & $\mathrm{n} / \mathrm{a}$ & $\mathrm{Y}$ \\
\hline 9. Eugenol & 29 & $\mathrm{Y}$ & $\mathrm{Y}$ & $\mathrm{n} / \mathrm{a}$ & $\mathrm{n} / \mathrm{a}$ & $\mathrm{n} / \mathrm{a}$ \\
\hline 10. Acetyl eugenol & 36 & $\mathrm{P}$ & $\mathrm{Y}$ & $\mathrm{Y}$ & $\mathrm{n} / \mathrm{a}$ & $\mathrm{Y}$ \\
\hline 11. Xanthotoxin, bergapten & 49 & $\mathrm{~N}$ & $\mathrm{Y}$ & Y & $\mathrm{Y}$ & $\mathrm{Y}$ \\
\hline 12. Xanthotoxol & 60 & $\mathrm{~N}$ & $\mathrm{Y}$ & $\mathrm{Y}$ & $\mathrm{Y}$ & $\mathrm{Y}$ \\
\hline 13. Adhyperforin, hyperforin & 71 & $\mathrm{~N}$ & $\mathrm{Y}$ & $\mathrm{n} / \mathrm{a}$ & $\mathrm{n} / \mathrm{a}$ & $\mathrm{n} / \mathrm{a}$ \\
\hline 14. Triglycerides & 79 & $\mathrm{~N}$ & $\mathrm{P}$ & $\mathrm{Y}$ & $\mathrm{Y}$ & $\mathrm{Y}$ \\
\hline 15. Euglobal IIb & 84 & $\mathrm{~N}$ & $\mathrm{P}$ & $\mathrm{Y}$ & $\mathrm{n} / \mathrm{a}$ & $\mathrm{Y}$ \\
\hline 16. Macrocarpal C & 95 & $\mathrm{~N}$ & $\mathrm{~N}$ & $\mathrm{P}$ & $\mathrm{n} / \mathrm{a}$ & $\mathrm{Y}$ \\
\hline 17. Chlorophyll $a$ & 96 & $\mathrm{~N}$ & $\mathrm{~N}$ & $\mathrm{P}$ & $\mathrm{Y}$ & $\mathrm{Y}$ \\
\hline 18. Macrocarpal A & 115 & $\mathrm{~N}$ & $\mathrm{~N}$ & $\mathrm{~N}$ & $\mathrm{n} / \mathrm{a}$ & $\mathrm{Y}$ \\
\hline \multicolumn{2}{|c|}{$\begin{array}{l}\text { 19. Limiting value of TPSA of low-polar BAS molecules for } \\
\text { the solvent (LTPSA) }\end{array}$} & $30 \pm 5$ & $85 \pm 5$ & $95 \pm 5$ & $110 \pm 5$ & $115 \pm 5$ \\
\hline \multicolumn{2}{|c|}{$\begin{array}{l}\text { 20. Relative proportion of fluorine atoms in solvent's } \\
\text { molecule }\left(\varphi_{F}\right)\end{array}$} & 0.63 & 0.50 & 0.47 & 0.40 & 0.13 \\
\hline
\end{tabular}

*Y means that BAS is extracted by the solvent during $3 \mathrm{~h}$ (yield $\geq 50 \%$ ); $\mathrm{N}$ means that BAS is not extracted by the solvent during $3 \mathrm{~h}$ (yield $\leq 10 \%)$; P means that BAS is poorly extracted by the solvent during $3 \mathrm{~h}(10 \% \leq$ yield $\leq 50 \%)$; ** $\mathrm{n} / \mathrm{a}$ means that data is not available.

Qualitative data on the possibility/impossibility of extraction of low-polar BAS, fluoroorganic solvent (lines 1 - 18) presented in Table III, allow to formalize and find the limit value of the molecular descriptor LTPSA of low-polar BAS for solvents (line 19) and associate it with the second molecular descriptor, the relative fraction of fluorine atoms in the solvent molecule $\left(\varphi_{F}\right)$ (line 20).

In the third part of the studies, the experimentally obtained data were compared as for LTPSA and $\varphi_{F}$ (lines 19, 20 in Table III) and the developed mathematical model (equation (5)) using regression analysis.

Figure 1 presents the experimental points and parameters of the regression line, which is constructed according to equation (5) in Origin 6.1 program.

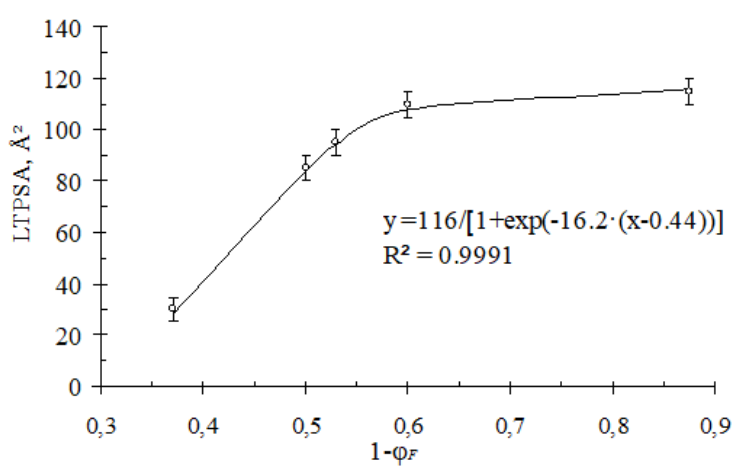

Figure 1.

The experimental data and parameters of the regression line 
From Figure 1 it is seen that the experimental data are in good agreement with the theoretically developed mathematical model in the form of equation (5) (empirical constants are $\mathrm{A}=116.0 \pm 1.3, \mathrm{k}=-16.2 \pm 0.6, \mathrm{~b}=$ $0.44 \pm 0.01$, and the coefficient of determination is $R^{2} \geq 0.99$ ), which gives grounds for adoption of working hypotheses that have been suggested to explain the extraction properties of fluoroorganic solvents.

It should be noted that constant $(A)$ in equation (5) can be interpreted as the maximum value of LTPSA molecular descriptor for low-polar BAS molecules, above which BAS molecules will not pass into the fluoroorganic solvent even with a minimum content of fluorine atoms. This is explained by the emergence of significant repulsive forces between the polar part of BAS molecules and solvent molecules.

In general, resulting equation (5) allows: (1) theoretical calculation of LTPSA value of BAS molecules that can be extracted with the fluoroorganic solvent with a given relative fraction of fluorine atoms in its molecule; (2) theoretical selection of the fluoroorganic solvent with the desired value of the parameter of relative fraction of fluorine atoms in its molecule for selective extraction of target low-polar BAS from PRM by their TPSA, and this parameter must meet the condition TPSA < LTPSA.

Thus, for the first time, the authors systematically studied the extraction properties of various fluoroorganic solvents with respect to low-polar BAS with a circulating extraction method in Soxhlet apparatus. The obtained data showed comparable results in environmental safety, toxicity, extraction time, and yield of BAS with the technology of liquefied gases and supercritical fluids, but at the same time demonstrate advantages in selectivity, simplicity of organization and conditions of the extraction process.

The use of these types of solvents is suitable for selective extraction of low-polar BAS; at the same time, the development of a new direction in the technology of integrated processing of PRM, which meets the basic principles of "green chemistry", is rather promising.

A mathematical model that allows predicting the possibility or impossibility of extraction of low-polar BAS molecules by the fluoroorganic solvent or, on the contrary, helps to choose the necessary type of the fluoroorganic solvent for extraction of a certain type of BAS has been suggested.

\section{Conclusions}

It has been found that the yield of low-polar BAS from PRM depends on the value of the polar part in the BAS molecule and the relative proportion of fluorine atoms in the fluoroorganic solvent molecule. A mathematical model that quantitatively describes the extraction properties of fluoroorganic solvents using molecular descriptors such as the relative fraction of fluorine atoms in the molecule of the fluoroorganic solvent and LTPSA has been developed. The developed mathematical model allows theoretical prediction and selection of the optimal type of the fluoroorganic solvent for selective extraction of target low-polar BAS from PRM. The obtained practical results showed advantages in selectivity, simplicity of organization, and conditions of the extraction process using fluoroorganic solvents in comparison with the technologies of liquefied gases and supercritical fluids, which is confirmed by a number of patents of the Russian Federation. Conducted systematic studies on extraction properties of various types of fluoroorganic solvents in regards to low-polar BAS from PRM, significantly expand our knowledge in the field of phytotechnology and can be used in the future for the development of new methods for isolation of different types of low-polar BAS on their basis.

\section{Acknowledgement}

Authors express their highest esteem and thanks to Dr. Sc. (Chem.), Prof. Mykola Blazheyevskiy of Physical and Colloid Chemistry Department, National University of Pharmacy, Kharkiv, Ukraine, for his help with the reference substances of anethole and eugenol.

Financial support and sponsorship

This research was funded by 5-100 program.

\section{Conflict of interest}

The authors declare no conflict of interest.

\section{References}

1. Georgievskiy VP, Konev FA, Editors. Technology and standardization of drugs: Collection of research papers. LLC "RIREG": Kharkiv, 1996, (available in Russian).

2. Chemat F, Vian MA, Editors. Alternative solvents for natural products extraction. Green chemistry and sustainable technology. Springer-Verlag: Berlin Heidelberg, 2014.

3. Coelho JP, Cristino AF, Matos PG, Rauter AP, Nobre BP, Mendes RL, Barroso JG, Mainar A, Urieta JS, Fareleira JMNA, Sovová H, Palavra AF, Extraction of volatile oil from aromatic plants with supercritical carbon dioxide: experiments and modeling. Molecules, 2012; 17(9): 10550-10573.

4. Sovová $\mathrm{H}$, Modeling the supercritical fluid extraction of essential oils from plant materials. J Chromatogr A., 2012; 1250: 27-33.

5. Fornari T, Vicente G, Vázquez E, García-Risco MR, Reglero G, Isolation of essential oil from different plants and herbs by supercritical fluid extraction. $J$ Chromatogr A., 2012; 1250: 34-48.

6. Mukhopadhyay M, Natural extracts using supercritical carbon dioxide. $1^{\text {st }}$ Ed. CRC Press Boca: Raton, USA, 2000. 
7. Banks RE, Smart BE, Tatlow JC, Editors. Organofluorine chemistry. Principles and commercial applications. Springer: New York, USA, 1994.

8. Zsila F, The un(f)told story of general anesthesia. ChemBioChem., 2018; 19(9): 895-901.

9. Thermostatic fluids 3M, www.3Mnovec.ru.

10. McCulloch A, Volatile anaesthetics and the atmosphere: atmospheric lifetimes and atmospheric effects of halothane, enflurane, isoflurane, desflurane and sevoflurane. BJA., 2000; 84(4): 534-536.

11. ChemSpider, Chemical structure database, www.chem spider.com.

12. U.S. National library of medicine. Toxnet - toxicology data network, https://toxnet.nlm.nih.gov.

13. U.S. National library of medicine. National center for biotechnology information. PubChem Database, https://pubchem.ncbi.nlm.nih.gov.

14. Flick EW, Editor. Industrial solvents handbook. $5^{\text {th }}$ ed. Noyes Data Corporation: Westwood, New Jersey, USA, 1998.

15. Tuma $\mathrm{P}$, Tousignant $\mathrm{L}$, Reducing emissions of PFC heat transfer fluids. In SEMI Technical Symposium, 3M Specialty Materials, 1-8, San Francisco, CA, USA, 16 July 2001, http://multimedia.3m.com/mws/media/ $122381 \mathrm{O} /$ reducing-emissions-of-pfcheat-transferfluids.pdf.

16. Lemaire B, Mompon B, Surbled I, Surbled M. Method for fractionating essential oils using at least fluorinated solvent. Patent EP 1307533 B1. C11B9/025. Pub. Date: 2003-05-07.

17. Lemaire B, Surbled M, Zwegers J, Mompon B, Method for extracting and fractionating fats with solvent, using at least a hydrofluroether. Patent US 6673952 B2. C11B 1/00. Pub. Date: Jan. 6, 2004.

18. Dournel P, Surbled M, Mompon B, Process for separating out at least one organic compound. Patent US 2006/0182689 A1. A61L 9/04, A61K 8/00, C07C 405/00, C07J 9/00, C07C 61/06. Pub. Date: Aug. 17, 2006.

19. Zhilyakova ET, Novikov OO, Pisarev DI, Malyutina AY, Boyko NN, Studying the polyphenolic structure of Laurus Nobilis L. leaves. Indo Am J Pharm Sci., 2017; 4(09): 3066-3074.

20. Hiemenz PC, Rajagopalan R, Principles of colloid and surface chemistry. $3^{\text {rd }}$ rev. and expanded Ed. Marcel Dekker Inc.: New York, USA, 1997.

21. Mannhold R, Editor. Molecular drug properties. Measurement and prediction. Wiley-VCH Verlag GmbH\&Co. KgaA: Weinheim, Germany, 2008.

22. Boyko NN, Pisarev DI, Zhilyakova ET, Malyutina AY, Novikov OO, A new technology for extraction of essential oil from Anethum graveolens L. fruits. Fine Chemical Technologies, 2019; 14(2): 33-40, (available in Russian).
23. Boyko NN, Pisarev DI, Zhilyakova ET, Malyutina AY, Novikov OO, A novel method for extraction of essential oil compounds from Foeniculum vulgare Mill. fruits. Problems of biological, medical and pharmaceutical chemistry. 2019; 22(5): 47-51, (available in Russian).

24. Boyko NN, Pisarev DI, Zhilyakova ET, Malyutina AY, Novikov OO, Kuznietsova VY, Sahaidak-Nikitiuk RV, Blazheyevskiy MY, Shpychak OS, Sushchuk NA, An innovative way for extraction of essential oil components from Pimpinella anisum L. fruits. Int $J$ App Pharm., 2019; 11(4): 83-87.

25. Bojko NN, Zhilyakova ET, Pisarev DI, Novikov OO, Nefedova LV, Method for extraction of essential oil from clove tree buds. Patent RU 2696127 C1. C11B9/02 (2006.01). Pub. Date: 01.08.2019. Bull.22, (available in Russian).

26. Bojko NN, Zhilyakova ET, Pisarev DI, Tsvetkova ZE, Novikov OO, Method of extracting essential oil from dill. Patent RU 2696132 C1. C11B9/00 (2006.01). Pub. Date: 01.08.2019. Bull.22, (available in Russian).

27. Bojko NN, Zhilyakova ET, Pisarev DI, Novikov OO, Nefedova LV, Method for production of essential oil of dill. Patent RU 2696134 C1. C11B9/00 (2006.01). Pub. Date: 01.08.2019. Bull.22, (available in Russian).

28. Bojko NN, Zhilyakova ET, Pisarev DI, Malyutina AY, Vasilev GV, Novikov OO, Method for extraction of essential oil from fennel fruits. Patent RU 2696308 C1. C11B9/00 (2006.01). Pub. Date: 01.08.2019. Bull.22, (available in Russian).

29. Bojko NN, Zhilyakova ET, Pisarev DI, Bondarev $\mathrm{AV}$, Novikov OO, Method for production of essential oil of common fennel fruits. Patent RU 2697097 C1. C11B9/00 (2006.01). Pub. Date: 12.08.2019. Bull.23, (available in Russian).

30. Bojko NN, Zhilyakova ET, Pisarev DI, Novikov OO, Mizina PG, Sajbel OL, Sidelnikova MK, Method of extracting euglobales of acyl floroglucinol-monoterpene series from eucalyptus. Patent RU 2700699 C1. A61K 36/61 (2006.01), A61K 127/00 (2006.01), B01D 11/02 (2006.01). Pub. Date: 19.09.2019. Bull.26, (available in Russian).

31. Boyko NN, Zhilyakova ET, Pisarev DI, Novikov OO, Sahaidak-Nikitiuk RV, Kuznietsova VY, Shpychak OS, Tkachev AV, Kovalenko AM, Sushchuk NA, A new way for extraction of main compounds of essential oil from clove buds. Farmacia, 2020; 68(1): 170-175.

32. Dowdle PA, Merseyside SSH, Corr S, Cheshire A, Harris H, Cheshire W, Solvent extraction process. Patent US 2004/0105899 A1. A61K 35/78. Pub. Date: Jun.3, 2004.

33. Santos DT, Meireles MAA, Extraction of volatile oils by supercritical fluid extraction: patent survey. Recent Pat Eng., 2011; 5(1): 17-22. 